\title{
Analisis Risiko Kesehatan Akibat Pajanan Senyawa Nitrat dan Nitrit Pada Air Tanah di Desa Cihambulu Subang
}

\author{
${\text { Mutia Ardhaneswari }{ }^{1^{*}} \text {, Bambang Wispriyono }}^{2}$ \\ 1 Program Studi Magister Ilmu Kesehatan Masyarakat, Fakultas Kesehatan Masyarakat, Universitas Indonesia \\ 2 Program Studi Magister Ilmu Kesehatan Masyarakat, Fakultas Kesehatan Masyarakat, Universitas Indonesia \\ *Corresponding author: ardha2207@gmail.com
}

Cara sitasi (Vancouver): Ardhaneswari M, Wispriyono B. Analisis Risiko Kesehatan Akibat Pajanan Senyawa Nitrat dan Nitrit Pada Air Tanah di Desa Cihambulu Subang. Jurnal Kesehatan Lingkungan Indonesia [Online]. 2022 Feb;21(1):65-72. https://doi.org/10.14710/jkli.21.1.65-72.

\begin{abstract}
ABSTRAK
Latar belakang: Penggunaan pupuk nitrogen seperti NPK dan urea pada lahan pertanian dapat menyebabkan pencemaran pada air tanah di wilayah pertanian. Pupuk nitrogen yang diaplikasikan pada tanah akan mengalami leaching terbawa air hujan masuk ke dalam tanah. Konsumsi air tanah yang mengandung nitrat dan nitrit dapat mengakibatkan dampak kesehatan seperti Blue Baby Syndrome atau Methemoglobinemia dan kanker. Penelitian ini dilakukan untuk menganalisis konsentrasi nitrat dan nitrit pada air tanah dan mengukur tingkat risiko kesehatan yang ditimbulkan dari kedua pajanan ini terhadap penduduk di Desa Cihambulu, Subang.

Metode: Penelitian ini dilakukan pada bulan Februari 2021 dengan menggunakan metode Analisis Risiko Kesehatan Lingkungan. Wawancara dilakukan kepada 123 responden dari 33 unit rumah tangga untuk memperoleh informasi berat badan, laju konsumsi dan lama tinggal responden di lokasi penelitian.. Sebanyak 33 sampel air tanah diambil dari 33 unit rumah tangga yang telah dilakukan wawancara. Pengukuran tingkat risiko kesehatan dilakukan dengan menghitung nilai Risk Quotion (RQ) dari masing-masing kelompok responden anak, wanita dan pria dewasa.

Hasil: Hasil analisis menunjukkan konsentrasi nitrat $\left(\mathrm{NO}_{3}-\mathrm{N}\right)$ pada air tanah berkisar antara 0,03 - 6,7 mg/L dengan rata-rata $1,38 \mathrm{mg} / \mathrm{L}$ sedangkan konsentrasi nitrit $\left(\mathrm{NO}_{2}-\mathrm{N}\right)$ pada air tanah berkisar antara $0,01-0,08 \mathrm{mg} / \mathrm{L}$ dengan rata-rata $0,02 \mathrm{mg} / \mathrm{L}$. Tingkat risiko kesehatan non karsinogenik menunjukkan nilai RQ $<1$ untuk 3 (tiga) kelompok responden yaitu anak, wanita dan pria dewasa.

Simpulan: Seluruh sampel air tanah masih memenuhi baku mutu dalam Peraturan Menteri Kesehatan Nomor 492/Menkes/Per/IV/2010 tentang Persyaratan Kualitas Air Minum, untuk parameter nitrat dan nitrit. Tingkat risiko kesehatan non karsinogenik yang disebabkan dari kedua pajanan tersebut pada air tanah menunjukkan nilai $\mathrm{RQ}<1$ dimana kedua pajanan tersebut belum beresiko menimbukan efek merugikan bagi kesehatan.
\end{abstract}

Kata kunci: Analisis Risiko Kesehatan; Nitrat; Nitrit

\section{ABSTRACT}

Title: Health Risk Assessment of Nitrate and Nitrite in Groundwater in the Agricultural Area, Cihambulu Village, Subang,

Background: The use of nitrogen fertilizers such as NPK and urea on agricultural land can cause contamination of groundwater in agricultural areas. Nitrogen fertilizer applied to the soil will be carried by rainwater into the soil. Consumption of groundwater containing nitrates and nitrites can lead to health effects such as Blue Baby Syndrome or Methemoglobinemia and cancer. This study was conducted to determine the 
concentration of nitrate and nitrite in groundwater and to determine the level of health risk posed by these two exposures to residents in Cihambulu Village, Subang..

Method: This study was conducted in February 2021 using the method of Environmental Health Risk Assessment. Interview were conducted with 123 respondents from 33 household units to obtain information on weight, consumption rate and length of stay of respondents in the study location. A total of 33 groundwater samples were taken from 33 household units that had been interviewed.

Result: The results shows that the concentration of nitrate $\left(\mathrm{NO}_{3}-\mathrm{N}\right)$ in groundwater ranged from $0.03-6.7 \mathrm{mg} / \mathrm{L}$ with an average of $1.38 \mathrm{mg} / \mathrm{L}$ while the concentration of nitrite $\left(\mathrm{NO}_{2}-\mathrm{N}\right)$ in groundwater ranged from $0.01-0.08$ $\mathrm{mg} / \mathrm{L}$ with an average of $0.02 \mathrm{mg} / \mathrm{L}$. The level of non-carcinogenic health risk shows an $R Q$ value $<1$ for 3 (three) groups of respondents, namely children, women and adult men.

Conclusion: All groundwater samples contain nitrate and nitrite within acceptable limits according to the requirements in the Regulation of the Minister of Health Number 492/Menkes/Per/IV/2010 concerning Requirements for Drinking Water Quality, especially nitrate and nitrite requirementrs. The level of noncarcinogenic health risk caused by this exposures to groundwater shows an $R Q$ value $<1$ where the two exposures are not at risk of causing adverse health effects.

Keywords: Health Risk Assessment; Nitrate; Nitrite

\section{PENDAHULUAN}

Penggunaan air tanah sebagai sumber air minum banyak digunakan oleh mayoritas penduduk di pedesaan. Salah satu permasalahan utama air tanah adalah terjadinya pencemaran air yang diakibatkan dari kegiatan pertanian. Kegiatan pertanian dengan penggunaan pupuk nitrogen dapat menyebebkan peningkatan konsentrasi senyawa nitrat dan nitrit pada air. Pupuk nitrogen seperti NPK dan urea merupakan sumber pencemaran air tanah pada wilayah pertanian. Pada tanah, pupuk NPK dan urea yang mengandung nitrogen akan diubah menjadi ammonia dan kemudian menjadi nitrit $\left(\mathrm{NO}_{2}\right)$ dan nitrat $\left(\mathrm{NO}_{3}\right)$. Nitrat yang terbentuk akan masuk ke dalam air tanah karena proses leaching (pencucian nitrogen) yang mengakibatkan penurunan kualitas air. ${ }^{(1,2)}$

Senyawa nitrat dan nitrit merupakan salah satu persyaratan kualitas air minum. World Health Organization (WHO) telah menerbitkan Guidelines for Drinking-water Quality yang menetapkan bahwa kandungan nitrat dan nitrit dalam air minum tidak boleh melebihi $50 \mathrm{mg} / \mathrm{L}$ untuk nitrat $\left(\mathrm{NO}_{3}{ }^{-}\right)$dan 3 $\mathrm{mg} / \mathrm{L}$ untuk nitrit $\left(\mathrm{NO}_{2}{ }^{-}\right) \cdot{ }^{(3)}$ The Environmental Protection Agency (EPA) telah mengatur batasan maksimum untuk nitrat dan nitrit yaitu masingmasing sebesar $10 \mathrm{mg} / \mathrm{L}$ untuk nitrat $\left(\mathrm{NO}_{3}-\mathrm{N}\right)$ dan 1 $\mathrm{mg} / \mathrm{L}$ untuk nitrit $\left(\mathrm{NO}_{2}-\mathrm{N}\right)$ dalam air minum yang aman. ${ }^{(4)}$ Perbedaan nilai konsentrasi maksimal nitrat dan nitrit ini disebabkan karena perbedaan pengukuran nitratnya, dimana WHO menetapkan 50 $\mathrm{mg} / \mathrm{L}$ (sebagai $\mathrm{NO}_{3}^{-}$) atau setara dengan $11 \mathrm{mg} / \mathrm{L}$ (sebagai $\mathrm{N}$ ) dan EPA menetapkan $10 \mathrm{mg} / \mathrm{L}$ (sebagai N). Di Indonesia, persyaratan konsentrasi nitrat dan nitrit dalam air minum telah diatur oleh Kementerian Kesehatan melalui Peraturan Menteri Kesehatan Nomor 492/Menkes/Per/IV/2010 tentang Persyaratan Kualitas Air Minum. Regulasi tersebut mempersyaratkan nitrat dan nitrit yang merupakan salah satu parameter wajib yang berhubungan langsung dengan kesehatan yaitu masing masing sebesar $50 \mathrm{mg} / \mathrm{L}$ untuk nitrat $\left(\mathrm{NO}_{3}{ }^{-}\right)$dan $3 \mathrm{mg} / \mathrm{L}$ untuk nitrit $\left(\mathrm{NO}_{2}^{-}\right)^{(5)}$

Senyawa nitrat dan nitrit yang masuk dalam tubuh manusia dalam konsentrasi yang tinggi dapat berpengaruh terhadap hematologi dan neurologis. Efek hematologi dari kedua pajanan ini adalah penyakit Blue Baby Syndrome atau Methemoglobinemia. Methemoglobinemia disebabkan karena terjadi oksidasi hemoglobin yang mengubah hemoglobin $\left(\mathrm{Fe}^{2+}\right)$ menjadi methemoglobin $\left(\mathrm{Fe}^{3+}\right) \cdot{ }^{(6)}$ Methemoglobin (MetHb) tidak dapat membawa oksigen sehingga bila jumlah methemoglobin di dalam tubuh melebihi kemampuan tubuh untuk mengkonversi kembali menjadi hemoglobin maka kondisi ini dapat menyebabkan sianosis, hipoksemia jaringan dan dalam kasus yang parah, kematian. ${ }^{(7)}$ Peningkatan MetHb dalam tubuh mengakibatkan menurunnya kemampuan darah membawa oksigen sehingga mengakibatkan kurangnya oksigen di berbagai bagian tubuh. Pada bayi berusia kurang dari enam bulan, nitrat dapat menyebabkan perkembangan methemoglobinemia, atau blue baby syndrom $^{(8)}$ yang bahkan dapat menyebabkan kematian neonatal. ${ }^{(9)}$ Efek neurologis pada manusia diakibatkan karena penurunan kemampuan darah untuk membawa oksigen dengan gejala klinis seperti pusing, kehilangan kesadaran dan kejang sebagai akibat dari konsumsi makanan atau minuman yang mengandung nitrit dengan konsentrasi tinggi. ${ }^{(10)}$ Selain itu senyawa nitrat dapat menyebabkan risiko terjadinya penyakit kanker pada orang dewasa. ${ }^{(11-17)}$

Desa Cihambulu merupakan salah satu desa penghasil padi di Kabupaten Subang, Jawa Barat. Luas areal persawahan yang dimiliki Desa Cihambulu sebesar 340 ha dengan dengan luas panen sebesar 788 ha. ${ }^{(18)}$ Wilayah pertanian dengan luas areal tanam yang luas mempengaruhi peningkatan penggunaan pupuk sehingga wilayah pertanian merupakan daerah yang memiliki potensi terjadinya pencemaran senyawa nitrat dan nitrit pada air tanah. Kondisi ini dapat menyebabkan risiko kesehatan pada manusia 
sehingga perlu diketahui status pencemaran nitrat dan nitrit saat ini dan tingkat risiko kesehatan pada saat ini. Oleh karena itu, tujuan dari penelitian ini adalah menganalisis konsentrasi nitrat dan nitrit pada sumber air penduduk di Desa Cihambulu serta mengukur tingkat risiko kesehatan non-karsinogenik yang ditimbulkan dari meminum air tanah yang terkontaminasi nitrat dan nitrit dengan menggunakan pendekatan Analisis Risiko Kesehatan Lingkungan.

\section{MATERI DAN METODE}

Penelitian ini menggunakan metode Analisis Risiko Kesehatan Lingkungan yang telah dinyatakan lolos kaji etik dengan nomor: Ket27/UN2.F10.D11/PPM.00.02/2021. Populasi dalam penelitian ini adalah penduduk Desa yang bertempat tinggal di Desa Cihambulu, Kabupaten Pabuaran, Subang. Subjek penelitian adalah penduduk tetap Desa Cihambulu yang bertempat tinggal di dekat lahan pertanian dengan kriteria inklusi sebagai berikut yaitu (i) menggunakan air tanah sebagai sumber air minum dan rumah tangga; (ii) tidak menggunakan sistem pemurnian atau penjernihan (filtrasi pada sumber airnya), (iii) Jarak lokasi tempat tinggal dengan areal persawahan dekat (radius maksimal 1,5 $\mathrm{km}$ ). Sedangkan untuk kriteria eksklusi untuk penelitian ini adalah bayi yang masih minum ASI. Pengambilan sampel dilakukan pada bulan Februari 2021 dan dilakukan secara purposive sampling. Sebanyak 123 responden yang memenuhi kriteria inklusi dan eksklusi diwawancarai. Pengambilan sampel air tanah diperoleh dari 33 sumur pribadi warga dari responden yang telah diwawancarai. Data atau informasi yang dikumpulkan meliputi data individu responden meliputi karakteristik individu (umur, jenis kelamin), berat badan, lamanya tinggal, jumlah konsumsi air minum, serta gejala kesehatan. Kondisi sumber air tanah seperti kedalaman, jarak sumber air dengan lahan pertanian, serta jenis pupuk yang digunakan, waktu pemberian pupuk juga dicatat dalam wawancara.

Pengambilan sampel air dilakuan dengan menggunakan botol plastik polietilen dengan jumlah sampel tiap rumah sebanyak 2x600 mL. Semua sampel air dianalisis di Laboratorium Pengujian Balai Besar Industri Agro (BBIA) yang berlokasi di Bogor. Analisis sampel air merujuk kepada metode pengujian SNI 01-3554-2006, Cara uji air minum dalam kemasan untuk nitrat dan SNI 06-6989-9-2004, Air dan air limbah -Bagian 9: Cara uji nitrit $\left(\mathrm{NO}_{2}-\mathrm{N}\right)$ secara spektrofotometri. Data yang diperoleh akan dilakukan analisis univariat untuk karakteristik responden, kondisi sumur, variabel konsentrasi nitrat dan nitrit pada air tanah, berat badan, laju asupan (banyaknya konsumsi air), lama tinggal (durasi pajanan) dengan SPSS versi 21. Selanjutnya, hasil dari analisis univariate tersebut akan digunakan dalam penentuan nilai intake (CDI) dan karakterisasi risiko, dimana untuk perhitungan karakterisasi risiko untuk penelitian ini dilakukan dengan model tingkat risiko non karsinogenik dengan persamaan sebagai berikut:

$$
\mathrm{RQ}=\mathrm{CDI} / \mathrm{RfD}
$$

Dimana RQ =tingkat risiko kesehatan; $\mathrm{CDI}=$ intake $(\mathrm{mg} / \mathrm{kg} /$ hari); $\mathrm{RfD}=$ dosis referensi $(\mathrm{mg} / \mathrm{kg} / \mathrm{hari})$

Untuk perhitungan CDI menggunakan persamaan berikut ini

\section{$\mathrm{CDI}=(\mathrm{C} \times \mathbf{R} \times \mathbf{f E} \times \mathbf{D t}) /(\mathrm{Wb} \times \operatorname{tavg}) \ldots \ldots \ldots \ldots(2)$}

Dimana $\mathrm{C}$ adalah konsentrasi nitrat dan nitrit pada air tanah (mg/L); $\mathrm{R}$ adalah laju asupan atau konsumsi(L/hari); $\mathrm{fE}$ adalah frekuensi pajanan (hari/tahun), Dt adalah durasi pajanan (tahun), Wb adalah berat badan $(\mathrm{kg})$, tavg adalah periode waktu rata-rata.

Dalam perhitungan nilai intake (CDI), digunakan data yang telah diperoleh sebagai berikut:

a) Konsentrasi Nitrat dan Nitrit dalam air tanah (C): diperoleh dari hasil pengujian sampel air yang diambil dari 33 lokasi

b) Laju konsumsi air minum (R): diperoleh dari informasi pola konsumsi

c) Frekuensi pajanan (fE): diperoleh dari nilai default, yaitu 350 hari/tahun (nilai default pada pemukiman residensial untuk jalur pajanan air minum berdasarkan US-EPA 1997) (19)

d) Durasi pajanan (Dt): diperoleh dari informasi lamanya responden tinggal di lokasi penelitian hingga penelitian dilaksanakan

e) Berat Badan (Wb): diperoleh dari hasil pengukuran berat badan responden saat wawancara

f) Periode bobot waktu rata-rata (tavg): diperoleh dari perhitungan nilai Dt x 365 hari/tahun

\section{HASIL DAN PEMBAHASAN}

\section{Karakteristik Responden}

Sebanyak 123 responden diperoleh berdasarkan kriteria inklusi dan eksklusi. Berdasarkan tabel 1, distribusi jenis kelamin paling banyak adalah perempuan yaitu sebanyak 64 orang $(52,0 \%)$ dan mayoritas responden berusia $\geq 18$ tahun sebanyak 88 orang $(71,5 \%)$. Untuk distribusi responden berdasarkan pekerjaan yang paling banyak adalah responden yang berprofesi sebagai petani sebanyak 32 orang $(26,0 \%)$. Responden yang berprofesi sebagai petani diwawancarai lebih lanjut untuk mendapatkan informasi terkait jenis pupuk yang digunakan dan waktu pemberian pupuk pada lahan pertaniannya. Sebanyak 32 orang (100\%) petani telah melakukan pemupukan pada lahan pertaniannya dengan menggunakan pupuk NPK dan urea pada bulan Desember 2020. 
Tabel 1. Distribusi Responden Berdasarkan Jenis Kelamin, Umur dan Pekerjaan Serta Kondisi Sumber Air di Desa Cihambulu Tahun 2021

\begin{tabular}{lcc}
\hline \multicolumn{1}{c}{ Variabel } & f & \% \\
\hline Jenis Kelamin & & \\
Laki-laki & 59 & 48,0 \\
Perempuan & 64 & 52,0 \\
Umur & & \\
$<18$ tahun & 35 & 28,5 \\
$\geq 18$ tahun & 88 & 71,5 \\
Pekerjaan & & \\
Petani & 32 & 26,0 \\
Pedagang & 5 & 4,1 \\
Buruh Bangunan & 2 & 1,6 \\
Ibu Rumah Tangga & 27 & 22,0 \\
Lainnya & 13 & 10,6 \\
Belum bekerja & 44 & 35,8 \\
Kedalaman sumur (m) & & \\
$\leq 30$ & 16 & 48,5 \\
$>30$ & 17 & 51,5 \\
Jarak Sumur (m) & & \\
$<100$ & 16 & 48,5 \\
100 - 500 & 8 & 24,2 \\
$>500$ & 9 & 27,3 \\
\hline
\end{tabular}

\section{Kondisi dan Lokasi Sumur}

Pengambilan sampel air diperoleh dari 33 sumur warga dengan kedalaman berbeda. Berdasarkan tabel 1, sebanyak $17(51,5 \%)$ sumur pribadi warga merupakan sumur dalam dengan kedalaman $>30$ meter. Untuk jarak sumber air tanah dengan lahan pertanian yaitu sebanyak $16(48,5 \%)$ sumur warga memiliki jarak yang cukup dekat yaitu $<100 \mathrm{~m}$ dari lahan pertanian.

\section{Konsentrasi Nitrat dan Nitrit Pada Air Tanah}

Hasil analisis menunjukkkan bahwa nitrat $\left(\mathrm{NO}_{3}-\right.$ N) pada air tanah berkisar antara $0,03-6,70 \mathrm{mg} / \mathrm{L}$ dengan rata-rata $1,38 \mathrm{mg} / \mathrm{L}$ sedangkan nitrit $\left(\mathrm{NO}_{2}-\mathrm{N}\right)$ pada air tanah berkisar antara 0,01 - 0,08 mg/L dengan rata-rata $0,02 \mathrm{mg} / \mathrm{L}$. Merujuk kepada nilai baku mutu pada Peraturan Menteri Kesehatan No. 492 Tahun 2010, dimana baku mutu nitrat sebesar 50 $\mathrm{mg} / \mathrm{L}\left(\mathrm{NO}_{3}{ }^{-}\right)$atau setara dengan $11,3 \mathrm{mg} / \mathrm{L}\left(\mathrm{NO}_{3}-\mathrm{N}\right.$ dan nitrit sebesar $3 \mathrm{mg} / \mathrm{L}\left(\mathrm{NO}_{2}-\mathrm{N}\right)$ atau setara dengan $0,9 \mathrm{mg} / \mathrm{L}$, maka seluruh sampel (100\%) masih memenuhi baku mutu tersebut.

Tabel 2. Konsentrasi Nitrat dan Nitrit Pada Air Tanah di Desa Cihambulu Tahun 2021

\begin{tabular}{cccc}
\hline Variabel & $\begin{array}{c}\text { Mean } \\
(\mathbf{m g} / \mathbf{L})\end{array}$ & SD & $\begin{array}{c}\text { Minimal-Maksimal } \\
(\mathbf{m g} / \mathbf{L})\end{array}$ \\
\hline Nitrat $\left(\mathrm{NO}_{3}-\mathrm{N}\right)$ & 1,38 & 1,99 & $0,03-6,70$ \\
Nitrit $\left(\mathrm{NO}_{2}-\mathrm{N}\right)$ & 0,02 & 0,03 & $0,01-0,08$ \\
\hline
\end{tabular}

Hasil penelitian untuk nitrat dan nitrit pada air tanah di lokasi ini menunjukkan nilai yang rendah yaitu berkisar $0,03-6,70 \mathrm{mg} / \mathrm{L}$ untuk nitrat $\left(\mathrm{NO}_{3}-\mathrm{N}\right)$ dan $0,01-0,08 \mathrm{mg} / \mathrm{L}$ untuk nitrit $\left(\mathrm{NO}_{2}-\mathrm{N}\right)$. Secara alami, senyawa nitrat terdapat pada air dalam konsentrasi rendah. Peningkatan konsentrasi nitrat diakibatkan dari kegiatan manusia seperti pertanian, pembuangan limbah dan peternakan. ${ }^{(21,22)}$ Penggunaan pupuk secara intensif dalam kegiatan pertanian berkontribusi terutama pada peningkatan kandungan nitrat dalam air tanah, dimana sawah dengan intensitas pemupukan lebih tinggi terbukti memiliki konsentrasi nitrat yang lebih besar dibandingkan sawah yang lebih sedikit dilakukan pemupukan ${ }^{(23)}$. Penelitian yang dilakukan Nejatijahromi et al. (2019) menemukan bahwa sumber utama kontaminasi nitrat pada air tanah berasal dari pupuk kimia ${ }^{(24) .}$ Di lokasi penelitian ini, pupuk NPK dan urea yang merupakan pupuk kimia digunakan secara luas oleh petani. Pupuk NPK dan urea yang mengandung nitrogen tersebut akan mengalami proses nitrifikasi dalam tanah dan menghasilkan senyawa nitrat dan nitrit. Proses perubahan pupuk khususnya pupuk urea menjadi nitrit dan nitrat terjadi pada minggu ke-4 setelah pemupukan ${ }^{(25)}$. Selanjutnya, kedua senyawa tersebut masuk ke dalam permukaan tanah karena terbawa oleh air hujan atau air irigasi.

Jumlah konsentrasi nitrat dan nitrit pada air tanah yang berada di bawah baku muku mengindikasikasikan bahwa nitrat dan nitrit yang berasal dari kegiatan pemupukan di areal pertanian tersebut dimungkinkan telah terbawa oleh aliran air irigasi. Sistem pengairan di lokasi pertanian ini menggunakan sistem bergilir (intermiten) dimana pengairan dilakukan sesuai kebutuhan. Pengairan dilakukan pada saat pengolahan tanah dan musim tanam. Aliran air pembuangan dari sawah satu akan mengalir dan dimanfaatkan kembali oleh sawah lainnya sehingga lahan sawah tidak tergenang dengan air. Aliran air pembuangan dari sawah terakhir akan keluar melalui saluran kecil dalam jumlah sedikit. Kondisi sistem pengairan di lokasi ini memungkinkankan nitrat pada pupuk terbawa aliran air irigasi ke sawah lainnya sehingga kemungkinan hanya sedikit nitrat yang masuk ke dalam tanah. Selain itu, kondisi lainnya yang mempengaruhi rendahnya konsentrasi nitrat di lokasi ini adalah pemupukan yang telah dilakukan 2 bulan sebelum pengambilan sampel air. Pemupukan dilakukan pada bulan Desember 2020 yang merupakan musin tanam, dimana pada saat itu juga dilakukan pengairan. Kondisi tersebut memungkinkan nitrat yang berasal dari pupuk telah terbawa aliran air pembuangan yang berasal dari irigasi sehingga tidak ada nitrat yang masuk ke dalam air tanah.

Faktor lainnya yaitu faktor musim juga dapat mempengaruhi tingkat konsentrasi nitrat pada air tanah, dimana konsentrasi nitrat yang lebih rendah pada air tanah ditemukan pada saat curah hujan tinggi. (26) Curah hujan yang tinggi akan menyebabkan 
terjadinya peningkatan serapan nitrogen pada tanaman dan mengurangi konsentrasi nitrat karena adanya efek pengenceran. Berdasarkan hasil wawancara kepada petani diperoleh informasi bahwa waktu pemberian pupuk dilakukan pada bulan Desember yang merupakan musim penghujan dan pengambilan sampel dilakukan 2 (bulan) setelah pemupukan yaitu bulan Februari. Faktor waktu pemupukan di musim hujan ini juga dapat menjadi salah satu faktor yang mempengaruhi rendahnya konsentrasi nitrat pada air tanah di lokasi ini.

Selain itu, tingkat konsentrasi nitrat pada air tanah dipengaruhi oleh jenis atau struktur tanah. Tanah dengan tekstur kasar, seperti pasir, memungkinkan nitrat meresap ke dalam air tanah lebih cepat dibandingkan tanah dengan tekstur halus seperti lempung atau tanah liat. ${ }^{(27)}$ Tekstur tanah sangat terkait dengan sifat fisik tanah tersebut seperti perkolasi atau permeabilitas. Semakin kasar teskstur tanah, maka laju perkolasi akan lebih cepat dan semakin halus tanah, maka laju perkolasi lambat. ${ }^{(27)}$ Tanah di lokasi penelitian merupakan jenis tanah alluvial, dimana tanah alluvial pada umumnya bertekstur halus, dengan kandungan fraksi liat $>50 \%$ ${ }^{(28)}$. Kondisi tanah yang bertekstur halus tersebut akan menghambat masuknya nitrat ke dalam air tanah sehingga konsentrasi nitrat pada air tanah di lokasi ini ditemukan dalam jumlah yang rendah.

Hasil analisis terhadap 33 sampel air diperoleh bahwa tingkat konsentrasi nitrit yang terdeteksi lebih rendah dibandingkan konsentrasi nitrat. Nitrit merupakan senyawa antara hasil dari perubahan ammonium menjadi nitrat pada proses nitrifikasi. Senyawa nitrit dihasilkan pada tahap pertama yang merupakan hasil oksidasi ammonium. Sifat nitrit yang tidak stabil dan mudah bereaksi dengan oksigen menjadi nitrat menyebabkan nitrit ditemukan dalam jumlah yang lebih kecil dibandingkan nitrat di air Proses nitrifikasi terjadi melalui 2 tahap sebagai berikut :

Tahap 1

$2 \mathrm{NH}_{4}++3 \mathrm{O} 2 \rightarrow 2 \mathrm{NO}_{2}{ }^{-}+2 \mathrm{H}_{2} \mathrm{O}+4 \mathrm{H}^{+}$

Tahap 2

$2 \mathrm{NO}_{2}{ }^{-}+\mathrm{O}_{2} \rightarrow 2 \mathrm{NO}_{3}^{-}$

Perhitungan nilai CDI nitrat dan nitrit berdasarkan rumus 2

CDI nitrat pada anak $\quad=1,38 \mathrm{mg} / \mathrm{L} \times 1,8 \mathrm{~L} /$ hari $\times 350$ hari/tahun $\times 8$ tahun

$25 \mathrm{~kg} \times 8$ tahun $\times 365$ hari/tahun

$=0,095 \mathrm{mg} / \mathrm{kg} / \mathrm{hari}$

CDI nitrit pada anak

$=0,02 \mathrm{mg} / \mathrm{L} \times 1,8 \mathrm{~L} /$ hari $\times 350$ hari/tahun $\times 8$ tahun

\section{Analisis Pajanan}

Pada penelitian ini, jalur utama masuknya nitrat dan nitrit pada air tanah ke dalam tubuh manusia adalah melalui konsumsi air minum atau melalui jalur ingesti sehingga perhitungan intake/asupan dari pajanan nitrat dan nitrit (CDI) dipengaruhi oleh konsentrasi nitrat dan nitrit pada air tanah, laju konsumsi (asupan), frekuensi pajanan, durasi pajanan dan berat badan. Untuk variabel frekuensi pajanan menggunakan nilai default yaitu 350 hari/tahun (nilai default pada pemukiman residensial untuk jalur pajanan air minum berdasarkan US-EPA 1997) (19) sedangkan variabel laju konsumsi, durasi pajanan dan berat badan berdasarkan informasi yang diperoleh saat wawancara kepada 123 responden. Untuk perhitungan nilai intake (CDI) berdasarkan 3 (tiga) kelompok responden, yaitu anak (usia $<18$ tahun), pria dewasa (usia $\geq 18$ tahun) dan wanita dewasa (usia $\geq 18$ tahun). Pembagian 3 kelompok responden ini mempertimbangkan pola aktivitas yang berbeda dari masing-masing kelompok responden. Nilai variabel laju konsumsi, durasi pajanan dan berat badan terdapat pada tabel 3 dan selanjutnya ketiga nilai tersebut akan digunakan dalam perhitungan CDI dan RQ.

Tabel 3. Variabel Laju Konsumsi, Durasi Pajanan dan Berat Badan Responden di Desa Cihambulu Tahun 2021

\begin{tabular}{lccc}
\hline & Anak & $\begin{array}{c}\text { Pria } \\
\text { Dewasa }\end{array}$ & $\begin{array}{c}\text { Wanita } \\
\text { Dewasa }\end{array}$ \\
\hline C Nitrat (mg/L) & 1,38 & 1,38 & 1,38 \\
C Nitrit (mg/L) & 0,02 & 0,02 & 0,02 \\
R (L/hari) & 1,8 & 1,8 & 2 \\
Dt (tahun) & 8 & 33 & 29 \\
fE (hari/tahun) & 350 & 350 & 350 \\
Wb (kg) & 25 & 64 & 56,2 \\
tavg (hari) & 2920 & 12045 & 10585 \\
\hline
\end{tabular}

$25 \mathrm{~kg} \times 8$ tahun $\times 365$ hari/tahun

$=0,0014 \mathrm{mg} / \mathrm{kg} / \mathrm{hari}$ 


\section{Analisis Dosis Respons}

Untuk melakukan analisis dosis repon ini, perlu diketahui jalur masuk pajanan nitrat dan nitrit masuk dalam tubuh, perubahan gejala atau efek kesehatan yang terjadi akibat peningkatan konsentrasi nitrat dan nitrit serta mengetahui dosis referensi (RfD). RfD adalah toksisitas kuantitatif nonkarsinogenik, menyatakan estimasi dosis pajanan harian yang diperkirakan tidak menimbulkan efek merugikan kesehatan meskipun pajanan berlanjut sepanjang hayat (19). Pada penelitian ini, nilai RfD untuk nitrat dan nitrit yang digunakan berdasarkan nilai referensi dari USEPA yang diterbitkan oleh Integrated Risk Information System (IRIS) yaitu masing-masing 1,6 $\mathrm{mg} / \mathrm{kg} /$ hari untuk nitrat $\left(\mathrm{NO}_{3}-\mathrm{N}\right)$ dan 1 x $10-1$ $\mathrm{mg} / \mathrm{kg} /$ hari untuk nitrit $\left.\left(\mathrm{NO}_{2}-\mathrm{N}\right)\right)(10,20)$.

\section{Karakterisasi Risiko}

Karakterisasi risiko dilakukan dengan mengukur tingkat risiko kesehatan yang ditimbulkan dari mengkonsumsi air minum yang mengandung nitrat dan nitrit. Tingkat risiko dinyatakan dalam nilai RQ (Risk Quotient) dengan membandingkan nilai CDI dengan nilai dosis refernsi (RfD) dari masing masing kedua pajanan nitrat dan nitrit tersebut, dengan persamaan rumus 1 . Nilai CDI dan RQ terdapat pada tabel 4.

Perhitungan nilai RQ nitrat pada anak

$$
\mathrm{RQ}_{\text {nitrat pada anak }}=\frac{\mathrm{CDI} \text { nitrat pada anak }}{\text { RfD nitrat }}
$$

RQ nitrat pada anak

$$
=\frac{0,095 \mathrm{mg} / \mathrm{kg} / \mathrm{hari}}{1,6 \mathrm{mg} / \mathrm{kg} / \text { hari }}
$$

RQ nitrat pada anak $\quad=0,060$

Perhitungan nilai RQ nitrat pada anak

$$
\begin{array}{ll}
\text { RQ nitrit pada anak } & =\frac{\text { CDI nitrit pada anak }}{\text { RfD nitrit }} \\
\text { RQ nitrit pada anak } & =\frac{0,0014 \mathrm{mg} / \mathrm{kg} \text { hari }}{0,1 \mathrm{mg} / \mathrm{kg} / \mathrm{hari}} \\
\text { RQ nitrit pada anak } & =0,014
\end{array}
$$

Tabel 4. Nilai Risk Quotion (RQ)

\begin{tabular}{lcccc}
\hline & \multicolumn{2}{c}{ CDI } & \multicolumn{2}{c}{ RQ } \\
& Nitrat & Nitrit & Nitrat & Nitrit \\
\hline Anak & 0,095 & 0,0014 & 0,060 & 0,014 \\
Pria Dewasa & 0,037 & 0,0005 & 0,023 & 0,005 \\
Wanita Dewasa & 0,047 & 0,0007 & 0,029 & 0,007 \\
\hline
\end{tabular}

Berdasarkan hasil analisis tingkat risiko kesehatan non karsinogenik dari kedua pajanan tersebut untuk setiap kelompok populasi menunjukkan nilai $\mathrm{RQ}<1$. Nilai $\mathrm{RQ}$ tersebut menggambarkan bahwa tidak ada dampak kesehatan dari konsumsi air tanah yang mengandung senyawa nitrat dan nitrit tersebut. Nilai RQ nitrat dan nitrit untuk kelompok responden anak lebih tinggi dibandingkan nilai $R Q$ pria dan wanita dewasa. Berdasarkan besarnya tingkat risiko senyawa nitrat maka dapat disimpulkan nilai RQ nitrat anak $>$ RQ nitrat wanita dewasa $>$ RQ nitrat pria dewasa begitu juga dengan besarnya tingkat risiko senyawa nitrit dari nilai $R Q$ terbesar yaitu $R Q$ nitrit anak > RQ nitrit wanita dewasa > RQ nitrit pria dewasa.

Nilai RQ dipengaruhi nilai intake dimana nilai intake yang semakin besar maka akan semakin besar kemungkinan terjadi gangguan kesehatan. Nilai intake untuk setiap kelompok populasi menunjukkan bahwa intake anak lebih besar dibandingkan orang dewasa (pria dan wanita), dimana nilai intake dipengaruhi oleh faktor pemajanan. Besarnya nilai intake berbanding lurus dengan nilai konsentrasi pajanan nitrat dan nitrit pada air minum, laju konsumsi, frekuensi pajanan dan durasi tinggal, sehingga semakin besar nilai variabel tersebut maka nilai intake akan semakin besar. Namun, nilai intake berbanding terbalik dengan berat badan dimana semakin kecil berat badan seseorang maka intake yang diterima akan semakin kecil, karena berdasarkan rumus intake (persamaan rumus 2) berat badan sebagai pembagi dalam rumus tersebut. Pada kondisi ini, dimana nilai intake anak lebih besar dibandingkan orang dewasa karena anak-anak mengkonsumsi lebih banyak air per kilogram berat badan mereka.

Hasil penilaian risiko kesehatan dapat dikaitkan dengan usia dimana risiko anak lebih tinggi dibandingkan orang dewasa. Kelompok anak khususnya anak berusia dibawah 5 tahun memiliki aktivitas reduktase B5 yang lebih rendah dalam sel darah merahnya dibandingkan orang dewasa, dimana enzim tersebut berfungsi mengubah MetHb menjadi $\mathrm{Hb}$ kembali sehingga risiko kesehatan pada anak khususnya usia dibawah 5 tahun lebih besar dibandingkan pada orang dewasa. Sedangkan pada orang dewasa dengan beberapa kondisi tertentu seperti tidak memiliki cukup asam lambung, kurangnya enzim yang berfungsi untuk mengubah sel darah merah menjadi normal kembali (methemoglobin reductase) dan wanita yang sedang hamil, dapat meningkatkan risiko kejadian methemoglobinemia (29). Selain itu, untuk responden berusia $>17$ tahun, jenis kelamin berpengaruh terhadap nilai RQ dimana penilaian risiko kesehatan pada wanita dewasa lebih tinggi dibandingkan pria dewasa. Hasil ini sejalan dengan penelitian Yuanzheng Zhai (2017) di Cina yang menunjukkan bahwa faktor usia dan jenis kelamin dianggap sebagai faktor utama yang mempengaruhi hasil penilaian risiko kesehatan manusia (30). 


\section{SIMPULAN}

Hasil penelitian untuk konsentrasi nitrat dan nitrit pada air tanah di wilayah Desa Cihambulu masih berada di bawah baku mutu yang dipersyaratkan. Untuk tingkat risiko kesehatan non karsinogenik menunjukkan nilai RQ $<1$ untuk kelompok responden yaitu anak, wanita dan pria dewasa yang menggambarkan bahwa senyawa nitrat dan nitrit pada air tanah tersebut belum menimbulkan risiko kesehatan kepada penduduk Desa Cihambulu sehingga saran yang diberikan untuk kegiatan pencegahan kepada Dinas Pertanian setempat agar dapat memberikan edukasi terkait pemupukan berimbang kepada petani yang bertujuan untuk meminimalkan masuknya nitrat atau ammonium ke dalam air tanah atau terbawa air permukaan.

\section{UCAPAN TERIMAKASIH}

Peneliti mengucapkan terimakasih kepada Kementerian Riset dan Teknologi/Badan Riset dan Inovasi Nasional yang telah memberikan dana penelitian, warga Desa Cihambulu serta Dinas Pertanian Kecamatan Pabuaran yang telah membantu terlaksananya penelitian ini.

\section{DAFTAR PUSTAKA}

1. Rivett MO, Buss SR, Morgan P, Smith JWN, Bemment CD. Nitrate attenuation in groundwater: A review of biogeochemical controlling processes. Water Res [Internet]. 2008 Oct;42(16):4215-32. Available from: https://doi.org/10.1016/j.watres.2008.07.020

2. Wang $\mathrm{Y}$, Ying $\mathrm{H}$, Yin $\mathrm{Y}$, Zheng $\mathrm{H}$, Cui $\mathrm{Z}$. Estimating soil nitrate leaching of nitrogen fertilizer from global meta-analysis. Sci Total Environ [Internet]. 2019;657:96-102. Available from:

https://doi.org/10.1016/j.scitotenv.2018.12.029

3. WHO. Water quality for drinking: WHO guidelines. Encyclopedia of Earth Sciences Series. 2011. 876-883 p. https://doi.org/10.1007/978-1-4020-4410-6_184

4. EPA. Consumer Factsheet on: Nitrates/Nitrites. 2014;4. Available from: https://archive.epa.gov/water/archive/web/pdf/ar chived-consumer-fact-sheet-on-nitrates-and-ornitrites.pdf

5. Republik Indonesia. Permenkes No. 492 Tentang Persyaratan Kualitas Air Minum. 2010.

6. Jaffé ER. Methemoglobin pathophysiology. Progress in clinical and biological research. 1981.

7. Manassaram DM, Backer LC, Messing R, Fleming LE, Luke B, Monteilh CP. Nitrates in drinking water and methemoglobin levels in pregnancy: a longitudinal study. Environ Heal [Internet]. 2010 Dec 14;9(1):60. Available from: https://doi.org/10.1186/1476-069X-9-60

8. Oftadeh BZG, Sany SBT, Alidadi H, Saghi M, Tafaghodi M, Shamszadeh SH, et al. Health Risk
Assessment of Nitrite and Nitrate in the Drinking Water in Mashhad, Iran. J Fasting Heal [Internet]. 2019;7(1):58-67. Available from: http://10.0.86.22/jnfh.2019.38879.1181\%0Ahttp: //search.ebscohost.com/login.aspx?direct=true\& $\mathrm{db}=\mathrm{a} 9 \mathrm{~h} \& \mathrm{AN}=139154892 \&$ site $=$ ehost-live

9. Rezaei H, Jafari A, Kamarehie B, Fakhri Y, Ghaderpoury A, Karami MA, et al. Health-risk assessment related to the fluoride, nitrate, and nitrite in the drinking water in the Sanandaj, Kurdistan County, Iran. Hum Ecol Risk Assess An Int J [Internet]. 2019 Jul 4;25(5):1242-50. Available from: https://www.tandfonline.com/doi/full/10.1080/1 0807039.2018.1463510

10. ATSDR. Toxicological Profile: Nitrate and Nitrite [Internet]. U.S. Department of Health and Human Services. 2017. 327 p. Available from: http://www.atsdr.cdc.gov/toxprofiles/TP.asp?id= $1452 \&$ tid $=258$

11. Sadler R, Maetam B, Edokpolo B, Connell D, $\mathrm{Yu}$ J, Stewart D, et al. Health risk assessment for exposure to nitrate in drinking water from village wells in Semarang, Indonesia. Environ Pollut [Internet]. 2016 Sep;216:738-45. Available from: https://linkinghub.elsevier.com/retrieve/pii/S026 9749116305309.

https://doi.org/10.1016/j.envpol.2016.06.041

12. Grosse Y, Baan R, Straif K, Secretan B, El Ghissassi F, Cogliano V, et al. Carcinogenicity of nitrate, nitrite, and cyanobacterial peptide toxins. The Lancet Oncology. 2006. https://doi.org/10.1016/S1470-2045(06)70789-6

13. Schullehner J, Hansen B, Thygesen M, Pedersen $\mathrm{CB}$, Sigsgaard T. Nitrate in drinking water and colorectal cancer risk: A nationwide populationbased cohort study. Int J Cancer. 2018;143(1):73-9.

https://doi.org/10.1002/ijc.31306

14. Espejo-Herrera N, Gràcia-Lavedan E, Boldo E, Aragonés N, Pérez-Gómez B, Pollán $\mathrm{M}$, et al. Colorectal cancer risk and nitrate exposure through drinking water and diet. Int $\mathrm{J}$ Cancer [Internet]. 2016 Jul 15;139(2):334-46. Available from:

https://onlinelibrary.wiley.com/doi/10.1002/ijc.3 0083

15. Jones RR, Weyer PJ, Dellavalle CT, Inoue-Choi $\mathrm{M}$, Anderson KE, Cantor KP, et al. Nitrate from drinking water and diet and bladder cancer among postmenopausal women in Iowa. Environ Health Perspect. 2016;124(11):1751-8. https://doi.org/10.1289/EHP191

16. Ward $\mathrm{MH}$. Nitrate Intake and the Risk of Thyroid Cancer and Thyroid Disease. 2014;23(1):1-7. Available from: https://www.ncbi.nlm.nih.gov/pmc/articles/PMC 3624763/pdf/nihms412728.pdf

17. Fathmawati. Nitrate in drinking water and risk of 
colorectal cancer in Yogyakarta, Indonesia. J Toxicol Environ Health [Internet]. 2017;80(2). Available from: https://www.tandfonline.com/doi/full/10.1080/1 5287394.2016.1260508?scroll=top\&needAccess $=$ true.

https://doi.org/10.1080/15287394.2016.1260508

18. BPS Subang. Kecamatan Pabuaran dalam Angka 2019 [Internet]. 2019. Available from: https://subangkab.bps.go.id/publication/2018/09/ 26/bc009df9d30bd820e63acf3c/kecamatanpabuaran-dalam-angka-2018.html

19. Rahman A. Analisis Risiko Kesehatan Lingkungan. 2017. p. 46.

20. U.S. Environmental Protection Agency. Chemical Assessment Summary for Nitrate; CASRN 14797-55-8 [Internet]. Integrated Risk Information System (IRIS). 1991. p. 1-11. Available from: https://cfpub.epa.gov/ncea/iris2/chemicalLandin g.cfm?substance_nmbr=76

21. WHO. Nitrate and Nitrite in Drinking Water. Nitrate and Nitrite in Drinking Water. 2011.

22. Zendehbad M, Cepuder P, Loiskandl W, Stumpp C. Source identification of nitrate contamination in the urban aquifer of Mashhad, Iran. J Hydrol Reg Stud [Internet]. 2019;25(March):100618. Available from: https://doi.org/10.1016/j.ejrh.2019.100618

23. Sunarti R. Sebaran konsentrasi Nitrat Pada Air Tanah Dangkal di Dataran Rendah Bekasi. 2009;

24. Nejatijahromi Z, Nassery HR, Hosono T, Nakhaei M, Alijani F, Okumura A. Groundwater nitrate contamination in an area using urban wastewaters for agricultural irrigation under arid climate condition, southeast of Tehran, Iran. Agric Water Manag [Internet].
2019;221(November 2018):397-414. Available from:

https://doi.org/10.1016/j.agwat.2019.04.015

25. Mawaddah A, Roto R, Suratman A. Pengaruh Penambahan Urea Terhadap Peningkatan Pencemaran Nitrit Dan Nitrat Dalam Tanah (Influence of Addition of Urea to Increased Pollution of Nitrite and Nitrate in The Soil). J Mns dan Lingkung [Internet]. 2017 Feb 27;23(3):360. Available from: https://journal.ugm.ac.id/JML/article/view/2247 3. https://doi.org/10.22146/jml.22473

26. Wick K, Heumesser C, Schmid E. Groundwater nitrate contamination: Factors and indicators. J Environ Manage [Internet]. 2012;111:178-86. Available from: http://dx.doi.org/10.1016/j.jenvman.2012.06.030

27. Al Hallaq AH. The impact of soil texture on nitrates leaching into groundwater in the north governorate, Gaza strip. J Soc Sci. 2010;38(2):11-35.

28. Prasetyo BH, Setyorini D. Karakteristik Tanah Sawah Dari Endapan Aluvial Dan Pengelolaannya. J Sumberd Lahan. 2012;2(1):114.

29. Washington State Department of Health. Nitrate in Drinking Water. In 2016.

30. Zhai Y, Lei Y, Wu J, Teng Y, Wang J, Zhao X, et al. Does the groundwater nitrate pollution in China pose a risk to human health? A critical review of published data. Environ Sci Pollut Res [Internet]. 2017 Feb 24;24(4):3640-53. Available from: http://link.springer.com/10.1007/s11356-0168088-9. https://doi.org/10.1007/s11356-0168088-9 